\title{
Geçici Koruma Statüsündeki Suriyelilerin Türkiye Ekonomisine Katılımı ve Entegrasyon Süreci
}




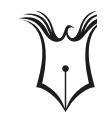

\section{(C) Copyright 2021}

Bu kitabın, basım, yayın ve satış hakları Akademisyen Kitabevi A.Ş.'ne aittir. Anılan kuruluşun izni alınmadan kitabın tümü ya da bölümleri mekanik, elektronik, fotokopi, manyetik kağıt ve/veya başka yöntemlerle çoğaltılamaz, basılamaz, dağıtılamaz. Tablo, şekil ve grafikler izin alınmadan, ticari amaçh kullamılamaz. Bu kitap T.C. Kültür Bakanlı̆̆ bandrolü ile satılmaktadır.

*Bu Çalışma Prof. Dr. Fatih YARDIMCIOĞLU Danışmanlığında Ahmet Akbulut’a Ait “Geçici Koruma Statüsündeki Suriyelilerin Türkiye Ekonomisine Katılımı ve Entegrasyon Süreci Üzerine Bir Analiz: İzmir İli Örneği” Adlı Doktora Tezinden Üretilmiștir.

\section{ISBN}

978-625-8037-28-9

\section{Kitap Adı}

Geçici Koruma Statüsündeki Suriyelilerin Türkiye Ekonomisine Katılımı ve Entegrasyon Süreci

\section{Yazar}

Ahmet AKBULUT

ORCID iD: 0000-0003-3573-9457

\section{Yayın Koordinatörü \\ Yasin DİLMEN}

\section{Sayfa ve Kapak Tasarımı}

Akademisyen Dizgi Ünitesi

\section{Yayıncı Sertifika No}

47518

\section{Baskı ve Cilt}

Vadi Matbaacılık

Bisac Code

BUS051000

DOI

10.37609/akya.841

\section{GENEL DAĞITIM}

\section{Akademisyen Kitabevi A.Ş.}

Halk Sokak 5 / A

Yenişehir / Ankara

Tel: 03124311633

siparis@akademisyen.com 


\section{ÖNSÖZ}

Suriye'de 2011 yılının başlarına doğru başlayan Arap Baharı da ülke içerisinde kaos ve kırılmalara sebep olmuş, bu çatışma ortamı 2011 yılından itibaren Suriye'den Türkiye'ye doğru ciddi bir göç dalgası başlamıştır.

Bu çalışmada, İzmir iline 2011 sonrası zorunlu olarak göç eden ve Türkiye Devleti tarafindan "Geçici Koruma" statüsü verilen Suriyelilerin, bulundukları kente ve birlikte yaşadıkları topluma karşı algılarının tespit edilerek ekonomik uyum süreçleri hakkında bilgi edinilmesi, sosyoekonomik sorunlarının tespit edilerek bu sorunlara bazı çözüm önerileri sunulması amaçlanmıştır. Çalışmada demografik ve sosyoekonomik sorulardan oluşan bir mülakat formu geliştirilmiştir. Çalışmada Suriyelilerin Türkiye'ye göç ettikten sonra burada kalmayı cazip hale getiren imkânlar da İzmir özelinde incelenmiştir. Bu çerçevede güvenlik, istihdam, Türklere kültürel yakınlık gibi faktörlerden hangilerinin göçün başlamasında ve göç ettikten sonra ülkeye tamamen yerleşme noktasında daha etkili olduğu incelenmiştir.

Yapılan çalışma, Suriyelilerin yaşadıkları fiziksel koşullar göz önünde bulundurulduğunda uyum sürecinin yabancı bir toplumun algısı dahilinde nasıl ilerlediğini anlayabilmek, yeni bir ülkeye alışma safhasında yerlerinden edilmiş yabancıların bireysel veya toplu olarak ne gibi sorunlar yaşadıklarını tespit edebilmek, ayrıca ekonomik uyum sürecinin uzun vadede daha sağlıklı yürütülebilmesi için karar alıcı ve uygulayıı bazı aktörlere de fikir verebilmek açısından önem kazanmaktadır.

Doktora tez çalışmamın yeniden gözden geçirilerek ve güncel verilerden faydalanılarak hazırlanan bu kitabın yazılma sürecinde son aşamasına kadar bana en büyük desteği veren, başta değerli hocam ve tez danışmanım Prof. Dr. Fatih YARDIMCIOĞLU 'na, tez jürilerimden Prof. Dr. Mehmet Barış HORZUM, Prof. Dr. Cemal IYEM, Doç. Dr. Adem KARAKAŞ, Doç. Dr. Furkan BEŞEL ve Dr. Eren Alper YILMAZ'a, ayrıca manevi desteklerini benden hiç bir zaman esirgemeyen kıymetli aileme teşekkürü bir borç bilirim.

Dr. Ahmet AKBULUT 
- 


\section{iÇINDEKILER}

GiRiş

\section{BÖLÜM}

\section{GÖÇÜN KAVRAMSAL ÇERÇEVESI}

1.1. Göç'ün Tanımı ve Göçle İlgili Diğer Kavramlar.... 5

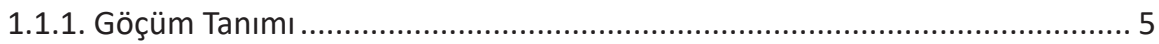

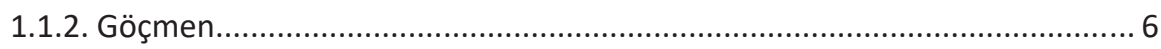

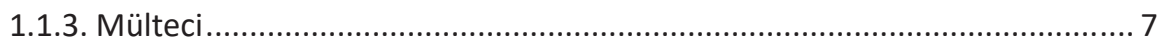

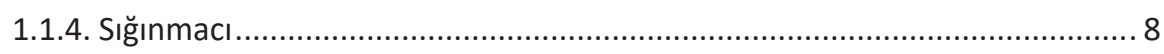

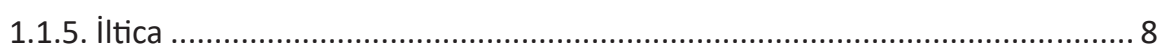

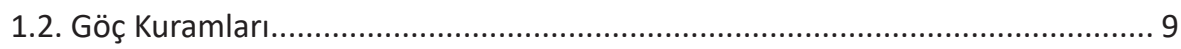

1.2.1. Ravenstein Göç Kuramı .............................................................................. 9

1.2.2. Kesişen Fırsatlar Kuramı ......................................................................... 12

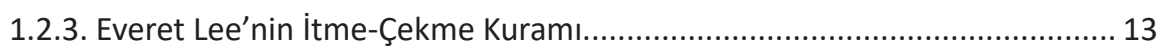

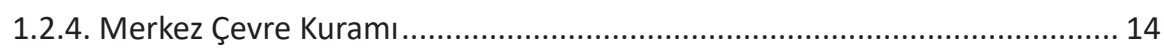

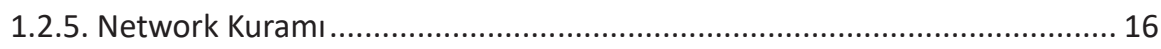

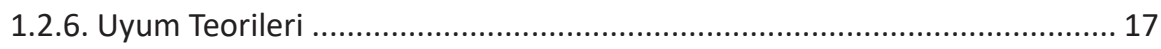

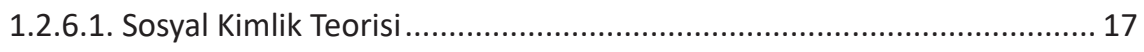

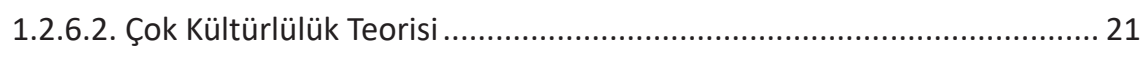

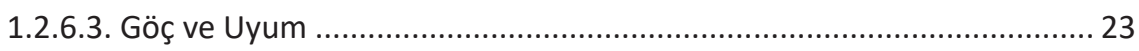

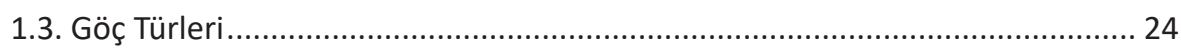

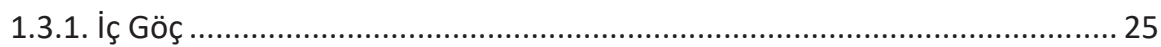

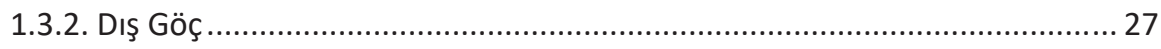

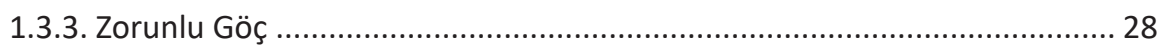

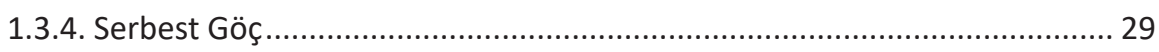

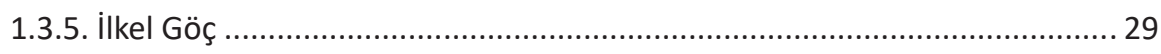

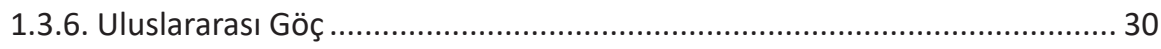

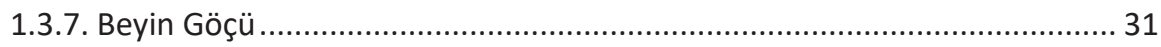

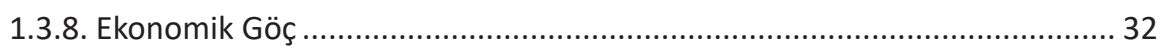

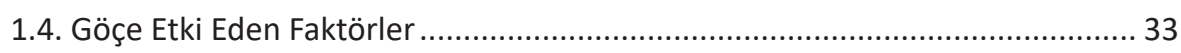

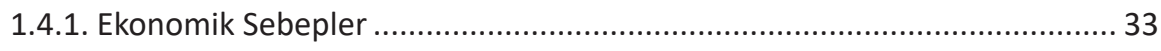

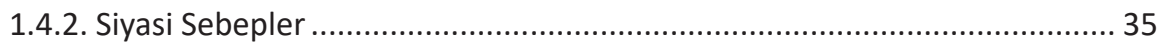

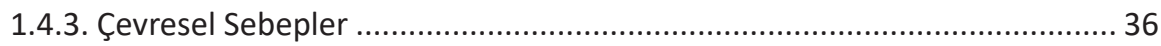




\section{BÖLÜM}

\section{ULUSAL VE ULUSLARASI SÖZLEŞMELER BAĞLAMINDA SURIYELI SIĞINMACILARIN ANALIZi}

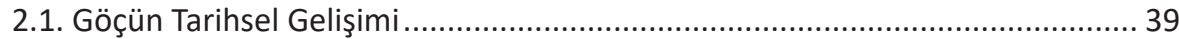

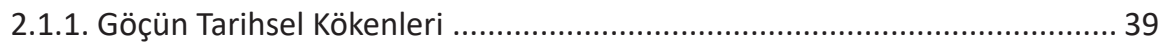

2.1.2. Suriye'den Türkiye'ye Gerçekleşen Göç Dalgası (2011- 2020)..................... 46

2.2. Mültecilere Yönelik Uluslararası Sözleşmeler................................................. 53

2.2.1. 1951 Mültecilerin Hukuki Statüsüne İlişkin Cenevre Sözleşmesi ................. 53

2.2.2. Mültecilerin Hukuki Statüsüyle İlgili 1967 Protokolü ................................. 57

2.2.3. 1984 Cartegena Mülteciler Bildirisi........................................................... 58

2.2.4. Schengen Anlaşması: Serbest Dolaşım İlkesi............................................. 59

2.2.5. Maastricht Antlaşması: Üç Sütunlu Yapıda Göç Politikası (1993).................60 60

2.2.6. Arap Birliği Sözleşmesi (27 Mart 1994) ...................................................... 61

2.2.7. Dublin Konvansiyonu ve Sığınmacıların Statüsü........................................6 62

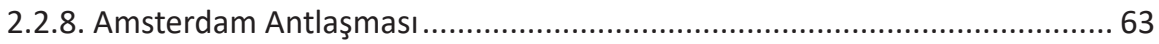

2.3. 6458 Sayılı Yabancılar ve Uluslararası Koruma Kanunu ....................................6 64

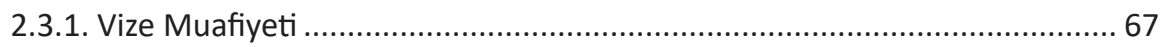

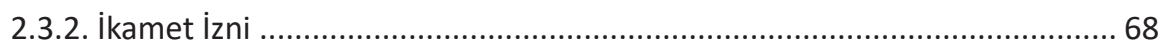

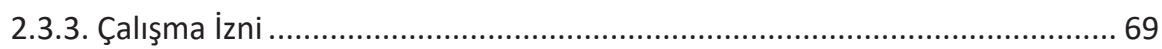

2.4. Geçici Koruma Yönetmeliği ......................................................................... 71

\section{BÖLÜM}

\section{SURIYELILERIN GÖÇ SÜRECINDE UYUMU}

3.1. Türkiye'deki Suriyelilerin Ekonomik Entegrasyon Süreci ................................. 75

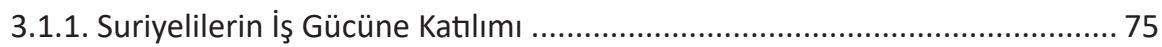

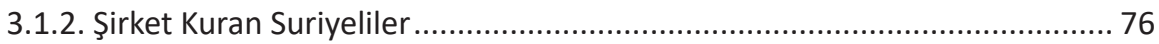

3.2. Türkiye'deki Suriyeli Sığınmacıların Yaşadığı Ekonomik Problemler ................. 86

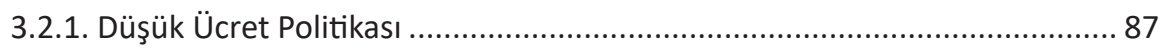

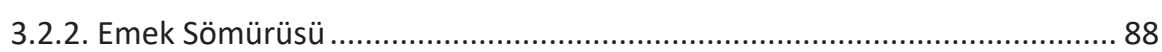

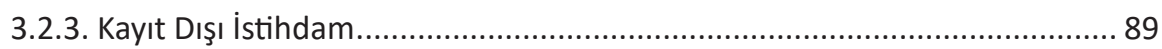

3.3. Ekonomik Entegrasyon Sürecine Destek Olan Kurumlar ................................ 93

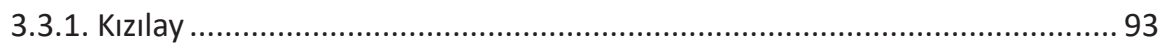

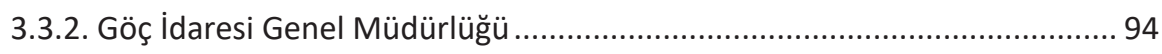

3.3.3. Afet ve Acil Durum Yönetimi Başkanlığı (AFAD) ........................................ 95 


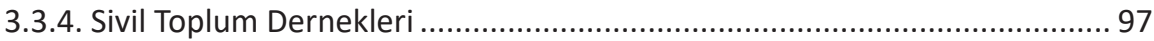

3.3.4.1. Insan Hak ve Hürriyetleri İnsani Yardım Vakf (iHH) ............................ 97

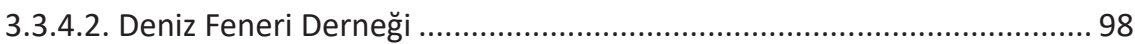

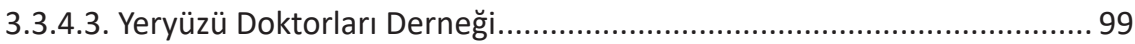

3.3.5. Uluslararası Kuruluşlar ......................................................................... 100

3.3.5.1. Birleşmiş Milletler Mülteciler Yüksek Komiserliği (UNHCR) ................. 101

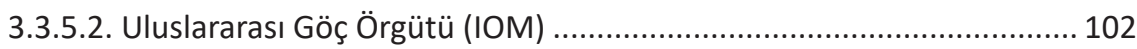

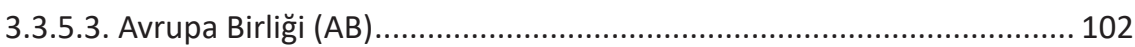

\section{BÖLÜM}

\section{IZMIR' DEKI SURIYELILERE YÖNELIK BİR SAHA ÇALIŞMASI}

4.1. Araştırmanın Amacı ve Önemi ..................................................................... 105

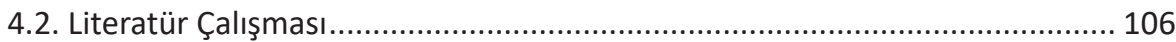

4.3. Araştırmanın Ön Kabulleri ve Sınırları ........................................................... 128

4.4. Çalışmada Kullanılan Yöntem ...................................................................... 129

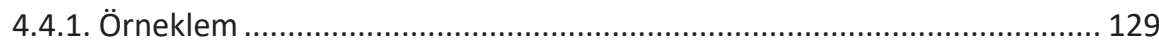

4.4.2. Mülakat İçin Veri Toplanmasına İlişkin Yöntem ......................................... 129

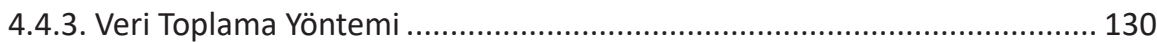

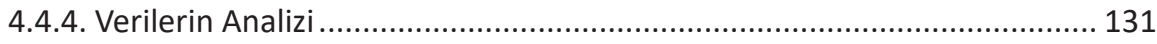

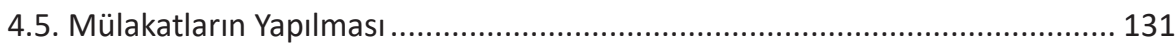

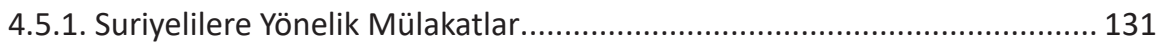

4.5.2. İzmir'de İşletme Sahibi Suriyelilere Yönelik Mülakat................................. 175

4.5.3. Devlet Kurumları ve Sivil Toplum Kuruluşlarına Yönelik Yapılan Mülakat.. 210

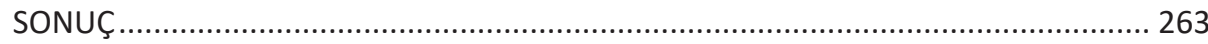

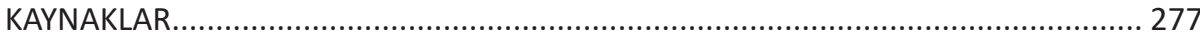

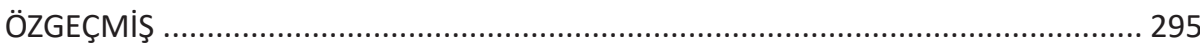


- 


\section{KISALTMALAR}

\begin{tabular}{|c|c|}
\hline AB & : Avrupa Birliği \\
\hline ABD & : Amerika Birleşik Devletleri \\
\hline AÇSHB & : Aile Çalışma ve Sosyal Hizmetler Bakanlığı \\
\hline AFAD & : Afet ve Acil Durum Yönetimi Başkanlığı \\
\hline AGIM & : Aydın Göç İdaresi Müdürlüğü \\
\hline AR-GE & : Araştırma ve Geliştirme \\
\hline AÜBK & : Arap Ülkeleri Birliği Konseyi \\
\hline BM & : Birleşmiş Milletler \\
\hline BMMYK & : Birleşmiş Milletler Mülteciler Yüksek Komiserliği \\
\hline ÇSGB & : Çalışma ve Sosyal Güvenlik Bakanlığı \\
\hline DFD & : Deniz Feneri Derneği \\
\hline EAY & : Eren Alper Yılmaz \\
\hline ESA & : Emine Sare Aydın \\
\hline GiGM & : Göç İdaresi Genel Müdürlüğü \\
\hline GSYiH & : Gayri Safi Yurt İçi Hasıla \\
\hline HÜGO & : Hacettepe Üniversitesi Göç ve Siyaset Araştırmaları Merkezi \\
\hline iDD & : İnsan Der Derneği \\
\hline ígim & : İzmir Göç İdaresi Müdürlüğü \\
\hline íGV & : İnsani Gelişme Vakfi \\
\hline İHD & : İzmir Hatuniye Derneği \\
\hline IHEB & : İnsan Hakları Evrensel Beyannamesi \\
\hline İHH & : İnsani Yardım Vakfi \\
\hline İKD & : İzmir Kızılay Derneği \\
\hline ILO & : Uluslararası Çalışma Örgütü \\
\hline IOM & : Uluslararası Göç Örgütü \\
\hline IRO & : Uluslararası Mülteci Örgütü \\
\hline
\end{tabular}




\begin{tabular}{|c|c|}
\hline IŞiD & : Irak Şam İslam Devleti \\
\hline KA & : Kadir Aydın \\
\hline KPD & : Kestane Pazarı Derneği \\
\hline MEB & : Milli Eğitim Bakanlığı \\
\hline MR & : Mustafa Raşit \\
\hline OECD & : Ekonomik İşbirliği ve Kalkınma Örgütü \\
\hline ORSAM & : Ortadoğu Stratejik Araştirmalar Merkezi \\
\hline RG & : Resmi Gazete \\
\hline STK & : Sivil Toplum Kuruluşları \\
\hline SUY & : Sosyal Uyum Yardım \\
\hline TAMP & : Türkiye Afete Müdahale Planı \\
\hline TEPAV & : Türkiye Ekonomi Politikaları Araştırma Vakfi \\
\hline TGR & : Türkiye Göç Raporu \\
\hline TiSK & : Türkiye İşveren Sendikaları Konfederasyonu \\
\hline TOBB & : Türkiye Odalar ve Borsalar Birliği \\
\hline TUik & : Türkiye İstatistik Kurumu Başkanlığı \\
\hline UNHCR & : Birleşmiş Milletler Mülteciler Yüksek Komiserliği \\
\hline UNICEF & : Birleşmiş Milletler Çocuklara Yardım Fonu \\
\hline WFP & : Dünya Gıda Programı \\
\hline YÖвіs & : Yabancı Öğrenci Bilgi İşletim Sistemine \\
\hline YÖK & : Yükseköğretim Kurulu Başkanlığı \\
\hline YUKK & : Yabancılar ve Uluslararası Koruma Kanunu \\
\hline
\end{tabular}




\section{KAYNAKLAR}

6458 Sayılı Yabancılar ve Uluslararası Koruma Kanunu Genel Gerekçesi. (2019). Erişim Tarihi: 12.07.2019 http://gib.icisleri.gov.tr/default_B0.aspx?content=1036. (Çevrimiçihttp://europa.eu/legislation_summaries/justice_freedom_security/free/ index_en.htm,09 temmuz 2019).

Abacı, C. (2016). Türkiye'de yaşayan Suriyeli göçmenlerin gündelik yaşam pratikleri: Mardin örneği. Muğla Sıtkı Koçman Üniversitesi, Sosyal Bilimler Enstitüsü, SosyoIoji Anabilim Dalı.

Abadan Unat N. (2017). Bitmeyen Göç Konuk İşçilikten Ulus-ötesi Yurttaşlığa. 3. Baskı, İstanbul: Bilgi Üniversitesi Yayınları.

Abadan-Unat, N. (2002). Bitmeyen Göç Konuk Iş̧̧ilikten Ulus-ötesi Yurttaşlığa. İstanbul: Bilgi Üniversitesi Yayınları.

Abrams, D. \& Hogg, M. A.(1988). Social İdentifications: A Social Psychology Of İntergroup Relations And Group Processes. Taylor \& Frances/Routledge.

Acer, Y., Kaya, İ., ve Gümüş, M. (2005). Küresel ve Bölgesel Perspektiften Türkiye'nin iltica Stratejisi. Ankara: Uşak Yayınları.

Açıkgöz, M. (2008). Türkiye'nin göç ve sığınma politikası: İnsan hakları ve güvenlik ikilemi. Yüksek Lisans tezi. Galatasaray Üniversitesi, Sosyal Bilimler Enstitüsü, Uluslararası İlişkiler Anabilim Dalı.

Adıgüzel, Y. (2018), Göç Sosyolojisi, Nobel Akademik Yayıncılık Eğitim Danışmanlık, Ankara. s.86.

Adıgüzel, Y. (2018), Göç Sosyolojisi, Nobel Akademik Yayıncılık Eğitim Danışmanlık, Ankara: s.200.

Afad (2009-2018) , Uluslararası İnsani Yardım Faaliyetleri

AFŞAR, M. (2004), "Doğrudan Yabancı Yatırımlar ve Bankacılık Sektörü" Ege Akademik Bakış Dergisi, Cilt;4, Sayı: 1-2A

Agosin, M. R. ve R. Mayer (2000). Foreign Investment In Developing Countries: Does It Crowd in Domestic Investment?, UNCTAD Discussion Paper, No: 146

Ak, B. U. (2021) Türkiye'de Farklı Koruma Statüsündeki Göçmenlerin İstihdam Deneyimleri. Doktora tezi. Hacettepe Üniversitesi, Sosyal Bilimler Ensitüsü, Sosyal Hizmet Anabilim Dalı.

Akan, Y. ve Arslan, İ. (2008). Göç Ekonomisi: Türkiye Üzerine Bir Uygulama. Bursa: Ekin Yayınevi.

Akbaba, E. (2018). Ahıska'dan Anadolu'ya göçler (1828-1921). Yüksek Lisans tezi. İstanbul Üniversitesi, Sosyal Bilimler Enstitüsü, Türkiyat Araştırmaları Anabilim Dalı.

Akbulat, E. F. (2017). Uluslararası Göç Ağları Ve Dayanışma Türkiye Ve Suriye Çerkesleri Buluşması: İstanbul Ve Balıkesir Orhanlı Ve Atköy Yerleşim Birimleri Örneği. Yüksek Lisans Tezi. Yeni Yüzyıl Üniversitesi, Sosyal Bilimler Enstitüsü, Siyaset Bilimi ve Uluslararası İlişkiler Anabilim Dalı,

Akcan, F. E. (1998). İstanbulda Suç Zanlısı Kadınlarda Kişilik Özelliklerinin Saptanması; Bunların Göç Ve Suç Özellikleriyle İlişkilendirilmesi. Yüksek Lisans Tezi. İstanbul Üniversitesi, Adli Tıp Enstitüsü, 
Akdeniz, E. (2014). Suriye savaşının gölgesinde: Mülteci işçiler. İstanbul: Evrensel Basım Yayın.

Akgül Yılmaz, G. (1998), "Yeralt Ekonomisinin Doğurduğu Vergi Kaybının Hesabı ile ilgili Yaklaşımlar ve Türkiye'de Yeralt Ekonomisinin Doğurduğu Vergi Kaybı", Marmara Üniversitesi IïBF Dergisi, 1998, s.486.

Akgün E. (2012). Yasadışı göç çerçevesinde Türkiye Avrupa Birliği ilişkileri. Doktora tezi. İstanbul Üniversitesi, Sosyal Bilimler Enstitüsü, Kamu Yönetimi Anabilim Dalı.

Akın, N. (1991). Bulgaristan'dan Zorunlu Göç Eden Soydaş Ailelerin Altı Yaş Grubu Çocuklarının Psiko-Sosyal Özelliklerinin İncelenmesi. Yüksek Lisans tezi. Hacettepe Üniversitesi, Sağlık Bilimleri Enstitüsü, Psikoloji.

Akkaya, B. (2006). Almanya'daki Türk Medyası Ve Türk Medyasının Türk Göçmenlerin Kültürel Yapısına Ve Entegrasyon Çabalarına Etkisi. Yüksek Lisans tezi. Sakarya Üniversitesi, Sosyal Bilimler Enstitüsü, Uluslararası Ilişkiler Anabilim Dalı.

Aksoy, Z. (2012). Uluslararası Göç ve Kültürlerarası Illetişim. Uluslararası Sosyal Araştırmalar Dergisi, 5(20): 292-303.

Akter, A. (2006). Tehcir Öncesi Vilayat-I Sitteden Amerika`ya Ermeni göçü. Doktora tezi. Dokuz Eylül Üniversitesi, Atatürk İlkeleri ve İnkılap Tarihi Enstitüsü, Türk İnkılap Tarihi.

Alabbas, M. (2018). Suriyeli göçmenlerin iş gücü piyasasına yönelik algılarının analizi: Gaziantep örneği. Yüksek Lisans tezi. Gaziantep Üniversitesi, Sosyal Bilimler Enstitüsü, İktisat Anabilim Dalı.

Alakuş, E. (2018). Türkiye'de göç yönetimi ve uygulaması. Yüksek Lisans tezi Bolu Abant İzzet Baysal Üniversitesi, Sosyal Bilimler Enstitüsü, Kamu Yönetimi Anabilim Dalı.

Alan, B. P. (2016). Türkiye'nin göç yönetimine yaklaşımı: Mevzuat ve uygulama. Yüksek Lisans tezi. İstanbul Üniversitesi, Sosyal Bilimler Enstitüsü, Siyaset Bilimi ve Uluslararası İlişkiler Anabilim Dalı,

Alkan, A. F. (2007). XIII. yüzyılda Anadolu'dan Mısır ve Suriye'ye yaşanan karşılıklı göçler. Yüksek Lisans tezi. Selçuk Üniversitesi, Sosyal Bilimler Enstitüsü, Tarih Anabilim Dalı.

Alu, P. (2018). Türkiye'de siyasi partilerin göç politdoikaları. Yüksek Lisans tezi. Çanakkale Onsekiz Mart Üniversitesi, Sosyal Bilimler Enstitüsü, Kamu Yönetimi Anabilim Dalı.Amsterdam Antlaşması, (2000), Haziran ss. 18-19.

Amnesty International. (2014). Syrian Refugees in Turkey. Erişim Tarihi: 06.10.2020https://www.amnesty.org/download/Documents/208000/eur440172014tr.pdf

Andiç, H. (2018). Kamu çalışanlarında göçmen algısı toplumsal kabul ve psikolojik entegrasyon üzerine bir araştırma. Yüksek Lisans tezi. Ardahan Üniversitesi, Sosyal Bilimler Enstitüsü, Siyaset Bilimi ve Kamu Yönetimi Anabilim Dalı.

Apak, H. (2014). Suriyeli göçmenlerin uyumu ve gelecek beklentileri: Mardin örneği. Mardin Artuklu Üniversitesi. Sosyal Bilimler Enstitüsü.

Aracl, D. T. (2018). Evaluating the impact of syrian refugees on Turkey's labor market: A synthetic control approach. Yüksek Lisans tezi. Boğaziçi Üniversitesi, Sosyal Bilimler Enstitüsü.

Ari, Y. O. (2018). Döngüsel göç hareketinin ekonomik belirleyicileri: Gürcistan-Türkiye örneği. Yüksek Lisans tezi. Karadeniz Teknik Üniversitesi, Sosyal Bilimler Enstitüsü, iktisat Bilim Dalı. 
Arslan, M. İ. (2012). Avrupa Birliği göç politikasının paradoksları ve Türk-AB ilişkilerine yansımaları. Yüksek Lisans tezi. Orta Doğu Teknik Üniversitesi, Sosyal Bilimler Enstitüsü, Uluslararası iliş̧kiler Anabilim Dalı.

Arslan, N. (2016). Beyin göçü ve kalkınma: Türkiye'nin kalkınmasında Türk bilim diaspora ağlarının rolü. Doktora tezi. İstanbul Üniversitesi, Sosyal Bilimler Enstitüsü, Çalışma Ekonomisi ve Endüstri İlişkileri Anabilim Dalı.

Arwen. (2008). Dünyadaki Göçlerin Nedenleri, https://www.delinetciler.org

Askerzoy, R. (2017). Uluslararası göçün güvenlikleştirme politikalarına etkisi: Almanya örneği. Yüksek Lisans tezi. Eskişehir Osmangazi Üniversitesi, Sosyal Bilimler Enstitüsü, Uluslararası İlişkiler Anabilim Dalı.

Ata, S. (2008). Avrupa Birliği'nde STK yönetimi: İspanya'da göç örneği. Yüksek Lisans tezi. Marmara Üniversitesi, Avrupa Birliği Enstitüsü, Avrupa Çalışmaları Anabilim Dalı.

Ataç, I. (2005). Avrupa Birliği'nde göçmen işçilerin çalışma hakları. , Yüksek Lisans tezi. Dokuz Eylül Üniversitesi, Sosyal Bilimler Enstitüsü, Avrupa Birliği Anabilim Dalı.

Atım, R. (2016). Yasadışı göç olayında transit ülke Türkiye. Yüksek Lisans tezi. Kırıkkale Üniversitesi, Sosyal Bilimler Enstitüsü, Sosyoloji Anabilim Dalı

Avcu, T. (2018). Avrupa'da aşırı sağ'ın yükselişinin göç politikalarına etkileri: Hollanda örneği. Yüksek Lisans tezi. Dokuz Eylül Üniversitesi, Sosyal Bilimler Enstitüsü, Kamu Yönetimi Anabilim Dalı.

Ay, Y. (2004). İç göç-suç ilişkisi: Mersin örneği. Yüksek Lisans tezi. Kara Harp Okulu Komutanlığı, Savunma Bilimleri Enstitüsü, Güvenlik Bilimleri Anabilim Dalı.

Ayaşlı, E. (2018). Mass migration movements to Turkey: The cases of Turks of Bulgaria, Northern Iraqis, and Syrians. Yüksek Lisans tezi. İhsan Doğramacı Bilkent Üniversitesi, Ekonomi ve Sosyal Bilimler Enstitüsü, Uluslararası Ilişkiler Anabilim Dalı.

Aybey, R./ Kibar, E.D. (2011). Yabancılar Hukuku, İstanbul: İstanbul Bilgi Üniversitesi Yayınları; s. 83.

Aydeniz, Y. (2018). Suriyeli sığınmacılar toplumsal uzamında zorunlu göç nedeni ile sınıf habitusunun aşınması: Muğla-Ortaca örneği. Yüksek Lisans tezi. Muğla Sıtkı Koçman Üniversitesi, Sosyal Bilimler Enstitüsü, Sosyoloji Anabilim Dalı. Yüksek Lisans tezi.

Aydın, G. (2016). Uluslararası Hukukta Deniz Yoluyla Gerçekleştirilen Yasa Dışı Göç İle Mücadele. Yüksek Lisans tezi. İstanbul Üniversitesi, Sosyal Bilimler Enstitüsü, Kamu Hukuku Anabilim Dalı.

Aydın, í. (2016). Dış göçlerin Türk Ekonomisine Etkileri: Suriye Kaynaklı Dış Göçün İktisadi Açıdan İncelenmesi Ve Değerlendirilmesi. Türk Hava Kurumu Üniversitesi, Sosyal Bilimler Enstitüsü, İşletme Anabilim Dalı.

Aydın, O. (2018). Sultanbeyli'de yaşayan geçici koruma statüsündeki Suriyeli göçmenlerin

Aydın, Ö. F. (2015). Türkiye'de Göçmen Kaçakçılığı Suçu ille Mücadelede Yasal Düzenlemelerin Rolü. Yüksek Lisans tezi. Çanakkale Onsekiz Mart Üniversitesi, Sosyal Bilimler Enstitüsü, Kamu Yönetimi Anabilim Dalı

Aygül Hasan Hüseyin (2018). Mülteci Emeğinin Türkiye İşgücü Piyasalarındaki Görünümü ve Etkileri Süleyman Demirel Üniversitesi Vizyoner Dergisi, Yıl: 2018, Cilt: 9, Sayı: 20, ss.68-82. 
Aytekin, S. T. (2018). Suriyeli Göçmen Ergenlerin Dayanıklılık Özelliklerinin İncelenmesi. Yüksek Lisans tezi. Ege Üniversitesi, Sosyal Bilimler Enstitüsü, Gelişim Psikolojisi Anabilim Dalı,

Banazılı, A. M. (2018). Avrupa Birliği ve Türkiye'de düzensiz göç yönetiminin geri kabul anlaşmaları üzerinden değerlendirilmesi. Yüksek Lisans tezi. İnönü Üniversitesi, Sosyal Bilimler Enstitüsü, Siyaset Bilimi ve Kamu Yönetimi Anabilim Dalı.

Bartram, D., Poros, M. V. ve Monforte, P. (2017), Göç Meselesinde Temel Kavramlar (Çev. I. A. Tuncay), Hece Yayınlar, Ankara.

Basa, N. (1989). Ekonomik gelişme ve göç olgusu -F. Almanya'da yabancı iş̧̧i istihdamı politikası. Doktora tezi. Uludağ Üniversitesi, Sosyal Bilimler Enstitüsü, Ekonomi Anabilim Dalı.

Başel, H. (2003). Sosyal Politika Açısından İç Göçler Sivas'tan İstanbul’a Göç Örneği. 1 (56): 316-390 dergipark.gov.tr/@halisbasel

Battal, K. (2018). Suriyeli göçmenlerin temsili: Türk Basınında Suriyeli Göçmenlere Dönük Yapılan Haberlerin Analizi. Yüksek Lisans tezi. İstanbul Arel Üniversitesi, Sosyal Bilimler Enstitüsü, Medya ve Kültürel Çalışmalar Anabilim Dalı.

Baykal, M. (2005). Uluslararası göçün soğuk savaş sonrası aldığı şekil ve bunun Türkiye ve Avrupa güvenliğine etkileri. Yüksek Lisans tezi. Harp Akademileri Komutanlığı, Stratejik Araştırmalar Enstitüsü, Uluslararası Ilişkiler Anabilim Dalı.

Baykul, B. P. (2012). Avrupa Birliği'nin yasa dışı göç politikası ve bu politikanın Türkiye'nin üyelik sürecine etkileri. Yüksek Lisans tezi. Atlım Üniversitesi, Sosyal Bilimler Enstitüsü, Uluslararası Illişkiler Anabilim Dalı..

Bayraklı, C.(2007).Dış Göçün Sosyo- Ekonomik Etkileri: Görece Göçmen Konutları'nda (İzmir) Yaşayan Bulgaristan Göçmenler Örneği, 1-174.

Bayraktar, H. (2007). Kırım ve Kafkasya'dan Adana Vilayeti'ne Yapılan Göç ve İskânlar (1869-1907). Türkiyat Araştırmaları Dergisi. Sayı: 405. ss. 405-434.

Bayraktar, I. (2011). Ulus ötesi evlilikler: Türkiye'den Almanya'ya aile birleşimi göçü. , Yüksek Lisans tezi. Orta Doğu Teknik Üniversitesi, Sosyal Bilimler Enstitüsü, Sosyal Politika Anabilim Dalı.

Baysan, Ç. (2018). Arap Baharı sonrası Türkiye’ye yerleşen göçmenlerin kariyer değişimleri. Yüksek Lisans tezi. Beykent Üniversitesi, Sosyal Bilimler Enstitüsü, İşletme Anabilim Dalı.

Beijcr, G. (1969). Modern Patterns of International Migratory Movements. Migration. Der. J. A . Jukson. Cambridge: Cambridge University Press.

Bektaş, H. (1994). Ermeni isyanları göç ettirilme nedenleri ve uygulamada devletin rolü. , Yüksek Lisans tezi. Marmara Üniversitesi, Sosyal Bilimler Enstitüsü, Türk İnkılap Tarihi.

Beth B. Hess; Elizabeth W. Markson ; Peter J. Stein, 1988 Sociology, MacMillan Publishing Company, New York, s. 505.

Bhagwati, J.(1985). International Migration And Investment, The Brain Drain İnternational Resource Flow Acconty Compsation Taxation and Related Propasals Black Well, Oxford, 1985 s.301).

Bilgili, M. (2006). Doğu Akdeniz kıyısında (Suriye, Lübnan, İsrail) yaşanan göçler ve devlet oluşum süreçlerine etkileri. Yüksek Lisans tezi. Marmara Üniversitesi, Ortadoğu Araşttrmaları Enstitüsü, Ortadoğu Coğrafyası Anabilim Dalı,

Bilgin, B. (2001). Türkiye'de Din Ve Laiklik. Ankara Üniversitesi Illahiyat Fakültesi Dergisi, $42(1), 41-58$ 
Bilir, M. (2014). Avrupa Birliği istihdam politikaları ve niteliksiz işgücü göçü. Yüksek Lisans tezi. İstanbul Üniversitesi, Sosyal Bilimler Enstitüsü, Avrupa Birliği Bilim Dalı.

Bingöl, A. S. (2006). Almanya ve Hollanda'da Türk göçmen işçi çocuklarına dönük eğitim politikaları ve uygulamaları. Yüksek Lisans tezi. Gazi Üniversitesi, Eğitim Bilimleri Enstitüsü, Eğitim Bilimleri Anabilim Dalı.

Birleşmiş Milletler, (1951) Cenevre Mültecilerin Hukuki Statüsüne Dair Sözleşme, md. 1-36.

BMMYK (1998). Sığınma ve Mülteci Konularındaki Uluslararası Belgeler ve Hukuki Metinler. Ankara: BMMYK

BMMYK, (1997). Sığınma İkilemi, Dünya Mültecilerinin Durumu, BMMYK.,

Boed, R. (1994-1995), "The State Of The Right Of Asylum In International Law", Duke Journal Of Comparative \& International Law, Vol: 5, s. 1-34.

Bozkaya, G. (2001). Göçmenlerin sosyal bütünleşme sorunları (Karapınar köyü örneği). Yüksek Lisans tezi. Sakarya Üniversitesi, Sosyal Bilimler Enstitüsü, Sosyoloji Anabilim Dalı,

Bozkurt, Enver Mehmet ÖZCAN, Arif KÖKTAŞ,(2008), Avrupa Birliği Mevzuat, Asil Yayın Dağıtım, Ankara, 2. Baskı

Bulkan, D. (2018). Avrupa Birliği göç politikası ve Suriyeli göçmenler. Yüksek Lisans tezi. İstanbul Medeniyet Üniversitesi, Sosyal Bilimler Enstitüsü, Uluslararası İlişkiler Anabilim Dalı.

Büyükçalık, M.E.(2015) Mülteci Hukukunun Gelişimi ve Türkiye'de Mültecilerin Sosyal Hakları, İstanbul, On İki Levha Yayınları.

Cagaptay, S., and Menekse, B. (2014). The Impact of syria's refugees on southern Turkey. Washington Institute for Near East Policy. Washington: http://www.washingtoninstitute.org/ (Erişim tarihi: 25.10.2019).

Canyurt, D. (2015). "Suriye Gelişmeleri Sonrası Suriyeli Mülteciler: Türkiye'de Riskler", Akademik Bakış Dergisi, Uluslararası Hakemli Sosyal Bilimler E- Dergisi sayı:48 Mart- Nisan 2015.

Castles, S. M. ve Miller, M. J. (2008). Göçler çağı: Modern dünyada uluslararası göç hareketleri (Çev: B. U. Bal ve İ. Akbulut). İstanbul: İstanbul Bilgi Üniversitesi Yayınları.

Castles, S., \& Miller, M. J. (2008). Göçler Çağı Modern Dünyada Uluslararası Göç Hareketleri. İstanbul: İstanbul Bilgi Üniversitesi Yayınları.

CAŞıN, Mesut Hakkı,(2013) Modern Uluslararası Hukukun Temel Esasları, Legal Yayıncılık, İstanbul

Cengiz, F. B. (2013). Türkiye'de sendikaların düzensiz emek göçüne bakışı: İstanbul örneği. Yüksek Lisans tezi. Marmara Üniversitesi, Sosyal Bilimler Enstitüsü, Çalışma Ekonomisi Bilim Dalı.

Civelek, İ. (1951). Tarihli Mültecilerin Hukuki Durumuna Dair Sözleşme. Uluslararası iliş̧kilerde Olaylar ve Yorumlar, Cilt 10, Sayı 35.

Condor, S. (1990) 'Social Stereotypes and Social Identity' in D. Abrams and M. Hogg (eds) Social Identity Theory: Constructive and Critical Advances. New York: Harvester Wheatsheaf.

Courbage, Y. and Fargues, P. 1997 Christians and Jews Under Islam, London I.B. Tauris

Czaika, M. (2013) The Effectiveness of Immigration Policies. Population and Development Review, 39 (3), 487-508 
Çağlayan, S. (2016). Bulgaristanıdan Türkiyesye göçler (Bulgaristan Halk Cumhuriyetìnin ilanından günümüze). Yayınlanmamış Yüksek lisans tezi. Ege Üniversitesi, Sosyal Bilimler Enstitüsü. Sosyoloji Anabilim Dalı.

Çakı, A. (2018). Geçmişten Bugüne Türkiyeınin Göç Politikası Ve Suriyeli Göçmenler Bağlamında Göç Yönetişimi. Yüksek Lisans tezi Karamanoğlu Mehmetbey Üniversitesi, Sosyal Bilimler Enstitüsü, Kamu Yönetimi Anabilim Dalı,.

Çakmak, S. (2018). Türkiyeınin göç politikaları: Suriyelilerin yerleştirilmesi örneği. Gazi Üniversitesi, Sosyal Bilimler Enstitüsü, Siyaset Bilimi ve Kamu Yönetimi Anabilim Dalı, Yüksek Lisans tezi.

Çanak, E.(2015). İkinci Dünya Savaşı Sırasında Balkanların İşgalinin Türkiye'ye Etkisi: Yahudi Mülteciler Meselesi. Turkish Studies, C. 10, S. 9, ss. 127-144.

Çavuşoğlu, H. (2006). Uluslararası Göç: Nedenleri, Tipleri, Türleri ve Göçmenler. FolkIor/Edebiyat Dergisi, 12 (48), 1-7.

Çayan, O. (2018). Uluslararası işgücü göçü ve işsizlik üzerine etkisi: 2009-2015 yılları arası Türkiye incelemesi. Selçuk Üniversitesi, Sosyal Bilimler Enstitüsü, İktisat Bilim Dalı, Yüksek Lisans tezi.

Çelebi, Ö. (2011). Kuramların sessizliği: liberalizm, realizm ve iltica rejiminin kuruluşu. Ö. Çelebi, S. Özçürümez ve ş. Türkay (Der.), íltica, uluslararası göç ve vatansızlık: Kuram, gözlem ve politika içinde(s. 9-26). Ankara: UNHCR

Çelik Fatih, (1999), Ekonomik Yönleriyle İç Göç Olgusu, Erciyes Üniversitesi Sosyal Bilimler Enstitüsü, (Yayınlanmamış Yüksek Lisans Tezi), Kayseri, s. 141

Çelik, D. Ş. (2018). Koşulluluk Bağlamında Düzensiz Göçle Mücadelede Avrupa Birliği Geri Kabul Anlaşmaları Ve Türkiyesye Yansımaları. Dokuz Eylül Üniversitesi, Sosyal Bilimler Enstitüsü, Avrupa Birliği Anabilim Dalı, Yüksek Lisans tezi.

Çelik, F. (2006). İç Göçlerin İtici ve Çekici Güçler Yaklaşımı Ille Analizi, Erciyes Üniversitesi İktisadi ve İdari Bilimler Fakültesi Dergisi, S.27, ss.149-170

Çelik, F. (2006). İç Göçlerin İtici ve Çekici Güçler Yaklaşımı İle Analizi, Erciyes Üniversitesi İktisadi ve İdari Bilimler Fakültesi Dergisi, S.27, ss.149-170

Çerçi, R. (2017). Uluslararası göç ve entegrasyonda yerel yönetimler: Hatay örneği. Mustafa Kemal Üniversitesi, Sosyal Bilimler Enstitüsü, Siyaset Bilimi ve Kamu Yönetimi Anabilim Dalı, Yüksek Lisans tezi.

Çetin, S. (2016). “Jiletli Teller” veya Bat Balkanlar'da Mültecileri Durdurma Stratejisinin Sonuçları. Liberal Düşünce Dergisi , (81) , 23-26

Çetiner, Ö. (2018). Göçün güvenlikleştirilmesi: Suriye krizi ve Avrupa Birliği. Çukurova Üniversitesi, Sosyal Bilimler Enstitüsü, Uluslararası İlişkiler Anabilim Dalı, Yüksek Lisans tezi.

Çetiner, S. (2020). Suriye krizi özelinde uluslararası göç sorunu, yönetimi ve uluslararası göç sorunun ev sahibi ülkeye sosyo-ekonomik etkileri: Türkiye örneği. Kahramanmaraş Sütçü İmam Üniversitesi, Sosyal Bilimler Üniversitesi, İktisat Anabilim Dalı.

Çiçekli, B. (2014). Yabancılar ve Mülteci Hukuku, Seçkin Yayıncılık. İstanbul

Çilingir, S. (2016). Müslüman göçmenlerin ötekileştirilmesi, güvenlikleştirilmesi ve entegrasyon çelişkisi: İngiltere örneği. Dokuz Eylül Üniversitesi, Sosyal Bilimler Enstitüsü, Avrupa Birliği Anabilim Dalı, Doktora tezi.

Çobangil, O. (2017). Türkiyesye dış göçle gelen nüfus hareketlerinin (Mülteciler ve sığınma arayanlar), kıyı-sınır kent yönetimine etkileri: İzmir-Basmane örneği. Dokuz Eylül Üniversitesi, Sosyal Bilimler Enstitüsü, Kamu Yönetimi Bilim Dalı, Yüksek Lisans tezi. 
Çoltu, S, Öztürk, S. (2018). Suriyeli Mültecilerin Türkiye Ekonomisine Etkileri. Balkan Sosyal Bilimler Dergisi, 7 (13) , 188-198.

Dalak, Ö. (2018). Güncel gelişmeler ışığında AB göç politikası. Dokuz Eylül Üniversitesi, Sosyal Bilimler Enstitüsü, Avrupa Birliği Anabilim Dalı, Yüksek Lisans tezi.

Değirmenci, G. (2011). Avrupa Birliği Göç Politikası Kapsamında Fransa'nın Göç Politikası, İstanbul Üniversitesi, Sosyal Bilimler Enstitüsü Avrupa Birliği Ana Bilim Dalı, Yüksek Lisans Tezi, İstanbul.

Demirtaş, H. (2009). Sakarya Üniversitesi, Sosyal Bilimler Enstitüsü, Mülteci Sorunu ve Türkiye - AB ilişkilerine etkisi, yayınlanmamış yüksek lisans tezi, Sakarya

Demirtaş, H. A. (2003), "Sosyal Kimlik Kuramı, Temel Kavram ve Varsayımlar", Iletişim Araştırmaları Dergisi,1(1), 123-144.

Dengiz, S. (2018). Göç hareketlerinin girişimcilik faaliyetleri üzerindeki etkisi: Hatay ili üzerine bir inceleme. Süleyman Demirel Üniversitesi, Sosyal Bilimler Enstitüsü, i̇ktisat Anabilim Dalı, Yüksek Lisans tezi.

Docquier, F. ve Rapoport, H. (2006), "The Brain Drain", New Palgrave Dictionary of Economic, s.2

Doğan, G. (2018). Mültecilerin göç durumu ve STK'ların bu duruma etkisi. İstanbul Arel Üniversitesi, Sosyal Bilimler Enstitüsü, Siyaset Bilimi ve Kamu Yönetimi Anabilim Dalı, Yüksek Lisans tezi.

Doğan, í. (2012).Sosyolojik Kavramlar ve Sorunlar, Pagem, Ankara

Doğan, K. (2008). Göçmen Kaçakçılığı Suçu. Ankara: Seçkin Yayıncılık.

Dönmez Kara., C. Ö. (2015). Göç Bağlamında Uluslararası İşbirliği ve Türkiye'nin Politikaları", Çanakkale On Sekiz Mart Üniversitesi. Sosyal Bilimler Enstitüsü. Uluslararası İlişkiler Anabilim Dalı, Doktora Tezi.

Durmaz, A. (2017). Beşeri Sermaye Kaynağı Olarak Diaspora: Almanya'daki Türkiye Kökenli Bilim İnsanlarının Türkiye İle Olan Bağlarının Tersine Beyin Göçü Üzerine Etkileri. Karadeniz Teknik Üniversitesi, Sosyal Bilimler Enstitüsü, İktisat Bilim Dalı, Yüksek Lisans tezi.

Dustmann C. and Glitz, A. (2005). "Immigration, Jobs and Wages: Theory, Evidence and Opinion", Centre for Research and Analysis of Migration, CEPR, London.

Dündar, F. (2008) İttihat ve Terakkiınin Müslümanları İskânı Politikası. İletişim Yayınları. İstanbul. S.251

Dündar, Fuat, (2008)Modern Türkiye'nin Şifresi: İttihat ve Terakki'nin Etnisite Mühendisliği 1913-1918, ed. Kerem Ünüvar, İletişim, İstanbul. s.32

Düzgün, A. N. (2018). Türkiye'deki Suriyeli Göçmen Kadınların Savaş Öncesi ve Sonrası Sahip Oldukları Sosyal Sermaye Değişiminin Araştırılması. İstanbul Üniversitesi, Sosyal Bilimler Enstitüsü, Kadın Çalışmaları Anabilim Dalı, Yüksek Lisans tezi.

Ekici, N. (2003). "Migration and Political Intervention: Diasporas in Transition Countries." In Migration and Political Intervention: Diasporas in Transition Countries, Berlin.

Ekonomik Kalkınma ve İşbirliği Örgütü (OECD), (2018), Uluslararası Göç Görünümü 2018, OECD Yayınları, Paris, https://doi.org/10.1787/migr_outlook-2019-en .

Ekşi Nuray ve Bülent Çiçekli,( 2012), Yabancı ve Mülteci Hukukuna Illişkin Danıştay 10. Daire Kararları, İstanbul: Beta, s. 185-186.

Ekşi, Nuray, (2016), Yabancılar ve Uluslararası Koruma Hukuku, İstanbul: Beta Yayınları, 4. Baskı, s. 169 
Ellemers, N., Spears, R., \& Doosje, B. (1997). Sticking together or falling apart: In-group identification as a psychological determinant of group commitment versus individual mobility. Journal of Personality and Social Psychology, 72(3), 70.

Elmas, Ş. (2016). Türkiye'de kaçak işgücü göçü yönetimi. Dokuz Eylül Üniversitesi, Sosyal Bilimler Enstitüsü, Çalışma Ekonomisi ve Endüstri İlişkileri Bilim Dalı, Yüksek Lisans tezi.

entegrasyon süreçlerine ilişkin niteliksel bir araştırma. Yüksek Lisans tezi. Maltepe Üniversitesi, Sosyal Bilimler Enstitüsü, Sosyoloji Anabilim Dalı.

Erbaş, S. (2013). Göçün yeniliğe katkısı: Almanya'daki Türkler üzerine bir değerlendirme. Dokuz Eylül Üniversitesi, Sosyal Bilimler Enstitüsü, Avrupa Birliği Bilim Dalı, Yüksek Lisans tezi.

Erdemir, G.D (2013). Türkiyenin Avrupa Birliği Entegrasyon Sürecinde Yasa Dışı Göç Ve Mülteci Sorunları. Trakya Üniversitesi, Sosyal Bilimler Enstitüsü, Uluslararası İlişkiler Anabilim Dalı, Yüksek Lisans tezi.

Erdoğan, F. (2018). Türkiye'ye yönelik yabancı göçün nedenleri üzerine bir değerlendirme (2000 ve sonrası). Marmara Üniversitesi, Orta Doğu ve İslam Ülkeleri Araştırmaları Enstitüsü, Ortadoğu Sosyolojisi ve Antropolojisi Anabilim Dalı, Yüksek Lisans tezi.

Erdoğan, M. (2017) “Kopuş”tan “Uyum”a Kent Mültecileri: Suriyeli Mülteciler ve Belediyelerin Süreç Yönetimi: İstanbul Örneği, Şehir ve Toplum (Göç Özel Sayısı), Marmara Belediyeler Birliği, Sayı:6, 13

Erdoğan, M. M. \& Ünver, C. (2015). Türk İş Dünyasının Türkiye'deki Suriyeliler Konusundaki Görüş, Beklenti ve Önerileri. Ankara: Matsa BasımeviTürkiye İşveren Sendikaları Konfederasyonu.

Erdoğan, M. M. (2015). Türkiye'deki Suriyeliler: Toplumsal Kabul ve Uyum. İstanbul Bilgi Üniversitesi Yayınları. İstanbul: İstanbul Bilgi Üniversitesi.

Erdoğan, S. \& Yazıcıoğlu, Y. (2014). Bilimsel Araştırma Nasıl Yapılır, Nasıl Yazılır, Beta Yayınları. İstanbul ss. 84

Ergüven, N, Sarp, ÖZTURANLI, Beyza (2013). Uluslararası mülteci hukuku ve Türkiye. (International Refugee Law and Turkey.). Ankara Üniversitesi Hukuk Fakültesi Dergisi. Cilt: 62 Sayı: 4 Sf: 1007-1061

Erten, S. (2018). Türkiye'de göç sorunsalı Suriye'den göçün etkileri Reyhanlı örneği. Hatay Mustafa Kemal Üniversitesi, Sosyal Bilimler Enstitüsü, Kamu Yönetimi ve Siyaset Bilimi Anabilim Dalı, Yüksek Lisans tezi.

Esenlikci, A. E. (2016). Avrupa Birliği'nde ve Türkiye'de göçmenlere yönelik sosyal politika düzenlemeleri. Karadeniz Teknik Üniversitesi, Sosyal Bilimler Enstitüsü, Çalışma Ekonomisi ve Endüstri İlişkileri Anabilim Dalı, Yüksek Lisans tezi.

Eş, M. ve Ateş, H, (2004). Kent yönetimi, kentlileşme ve göç: sorunlar ve çözüm önerileri, Sosyal Siyaset Konferansları Dergisi, (48), 206-246.

Euronews.com (2020). ab-den-6-milyar-euroluk-s-g-nmac-yard-m-anlasmas-n-n-400milyonluk-k-sm-na-imza, Erişim Tarihi: 17Mart 2019.

Farrokhzad, A. (2018). İnsan ticareti ve göçmen kaçakçılığı suçları. Ankara Üniversitesi, Sosyal Bilimler Enstitüsü, Kamu Hukuku Bilim Dalı, Doktora tezi.

Firik, (2010). TBMM İnsan Haklarını İnceleme Komisyonu. (2010). İnsan Hakları Işığında Türkiye'de Bulunan Mülteciler, Sığınmacılar ve Yasadışı Göçmenlerin Sorunları. (M. FiRiK, Dü.) Ankara: TBMM Basımevi s. 223. 
Fortney, J. (1972). Immigrant Professionals a Brief Historical Survey (Vol. 6, Ser. 1). Duke University, North Calorina: Center for the Study of Aging and Human Development, Duke University. S.52

Geçici Koruma Yönetmeliği, (2014), s.6213.

Geçici Koruma. (2018). Erişim Tarihi: 11.07.2019 http://www.goc.gov.tr/icerik6/gecici-koruma_409_546_552_icerik

Genç, D. (2005). Çokkültürlülük ve Avrupa toplumlarında göçmen entegrasyonu. Marmara Üniversitesi, Avrupa Birliği Enstitüsü, Siyasal Bilimler, Yüksek Lisans tezi.

Gençağa Kaya, N. (2002). Almanya daki Türk göçmenlerin sosyo-ekonomik gelişimi. Orta Doğu Teknik Üniversitesi, Sosyal Bilimler Enstitüsü, Ekonomi, Yüksek Lisans tezi.

Gençler, A. (2002). Yabancı Kaçak İşçilik Gerçeği ve Türkiye Örneği. Tühis İş Hukuku ve İktisat Dergisi, 17(3), 28-46.

Gençler, Ayhan. (2004). Avrupa Birliği'nin Göç Politikası, Sosyal Siyaset Konferansları Dergisi, Prof. Dr. Turan Yazgan'a Armağan Özel Sayısı, sayı: 49.

Georgeon, F. (2005). Türk Milliyetçiliğinin Kökenleri Yusuf Akçura. İstanbul: Tarih Vakfi Yurt Yayınları.

Giddens A. and Sutton P.W. (2014). Sosyolojide Temel Kavramlar. Ankara: Phoenix Yayınevi.

Giddens, A. ve Sutton, P. W. (2016). Sosyoloji (Çev: Mesut Şenol), (7.edisyon). İstanbul: Kırmızı Yayınları

Göç İdaresi Genel Müdürlüğü, (2016), "2016 Türkiye Göç Raporu”

Göç İdaresi Genel Müdürlüğü, "https://www.goc.gov.tr/goc-tarihi” Erişim Tarihi: 07.10 .2020

Göç İdaresi Genel Müdürlüğü, http://www.goc.gov.tr/icerik/butce_308_4606, Erişim Tarihi: 13.05 .2020

Göç İdaresi Genel Müdürlüğü. (2015). Türkiye ve Göç. Ankara: Göç İdaresi Genel Müdürlüğü Yayınları.

Göğebakan, A. (2018). The impact of syrian immigrants on the wages of unskilled natives in Turkey. Boğaziçi Üniversitesi, Sosyal Bilimler Enstitüsü, Yüksek Lisans tezi.

Göğer, E. (1979). Yabancılar Hukuku, 3. Bası, Ankara, s. 31

Göğer, E. (1979). Yabancılar Hukuku, Ankara: Ankara Üniversitesi Hukuk Fakültesi Yayınları. C:3, s. 31.

Gül, K.O..(2007).Doğu Türkistan Türkiye Göç İdaresi, www.goc.gov.tr

Güleç C. (2015). Avrupa Birliği'nin Göç Politikaları Ve Türkiye'ye Yansımaları, Tesam Akademi Dergisi - Turkish Journal Of Tesam Academy. 2 (2). 81 - 100.

Güllüpınar, F.. (2012). Göç Olgusunun Ekonomi- Politiği ve Uluslararası Göç Kuramları Üzerine Bir Değerlendirme, Anadolu Üniversitesi, Edebiyat Fakültesi Sosyoloji Bölümü

Güloglu, T. (2005). The Reality of Informal Employment in Turkey. Ithaca, NY: Cornell University, School of Industrial and Labor Relations, International Programs.

Güloğlu, T.,. (2012). Türkiye'de kayıt dışı istihdam gerçeğine bir bakış. ss.51-95

Gümüş, A. K. (2018). Suriye'den Türkiye'ye göçün sosyo-ekonomik ve kültürel yansımaları (Gaziantep örneği). Niğde Ömer Halisdemir Üniversitesi, Sosyal Bilimler Enstitüsü, Sosyoloji Anabilim Dalı, Yüksek Lisans tezi. 
Gündoğdu, A, Dizman, A. (2012). İstanbul Finans Merkezi Projesinin Swot Analizi i̇le Değerlendirilmesi Ve Dünya Finans Merkezleri ile Kıyaslanması. Ekonomi Bilimleri Dergisi, 5 (1) , 1-15

Güner, C.(2007). “iltica Konusunda Türkiye'nin Yol Haritası: Ulusal Eylem Planı”, AÜHFD, C. 56, Ss. 4.

Güneş, M. (2013). Uluslararası göçün tetikleyicileri: Suriye'den Türkiye'ye zorunlu göç'ün Cilvegözü örneği ile yansımaları. Turgut Özal Üniversitesi. Sosyal Bilimler Enstitüsü.

Güngör, N. D. (2003). Türkiye`den yurt dışına beyin göçü: Yurt Dışında Okuyan Öğrencilerin Ve Yüksek Öğrenimli İşücünün Dönme Niyetleri Üzerine Deneysel Bir ÇaIışma. Orta Doğu Teknik Üniversitesi, Sosyal Bilimler Enstitüsü, Ekonomi, Doktora tezi.

Gürkaynak, H.(1970). "Beyin Göçü ve Sömürgecilik”, Yeni Gazete, 18 Ekim 1970, s. 2., ve Doğan Atılgan, "Beyin Göçü”, Türkiye Kütüphaneciler Derneği, C. 35, S. 3, 1986, s. 27)

Güvenç, B.(1999). İnsan ve Kültür, Ankara: Remzi Kitabevi.

Hasan Kalyoncu Üniversitesi, Sosyal Bilimler Enstitüsü, İktisat Anabilim Dalı, Yüksek Lisans tezi.

Haug, S. (2008). "Migration Networks and Migration Desicion-Making". Journal of Ethnic and Migration Studies. 34(4), p.588.

Hayter, T. (2004). Open borders: the case against immigration controls (2th edition). London: Pluto Press.

Hinkle, S., \& Brown, R. J. (1990). Intergroup comparisons and social identity. In D. Abrams, \& M. A. Hogg (Eds.), Social identity theory: Constructive and critical advances (pp. 48-70). New York: Springer Verlag.

Hogg, M. A. and Mcgarty, C. (1990), Social Identity Theory: Constructive and Critical Advances. London: Harvester Wheatsheaf.

Hogg, M. A., \& Williams, K. D. (2000). From I to we: Social identity and the collective self. Group Dynamics: Theory, Research, and Practice, 4(1), 81-97.

Hogg, M. A., \& Vaughan, G. M. (1995). Social psychology: An introduction. Prentice-Hall, Inc; Harvester Wheatsheaf.

Hugo G. (2011). “Changing Spatial Patterns of Immigrant Settlement”. Multiculturalism and Integration: A Harmonious Relationship (Michael CLYNE ve James JUPP Eds.) Australia 2011.

http://aa.com.tr/tr/dunya/siginmaci-krizi-dublin-sozlesmesini-askiya-aldirdi/12842., Erişim Tarihi: 10.07.2019.

http://www.tcmb.gov.tr/(2014) kurlar Temmuz tarihli 2,12 ortalama kuru üzerinden: 462 TL, /kur2014_tr.html, Erş. Tar. 15.02.2020 "http://www.hurriyet.com.tr/ (2014), ekonomi/27005301.asp, 10.02.2020).

https://www.aa.com.tr/tr/dunya/siginmaci-krizi-dublin-sozlesmesini-askiya-aldirdi/12842 erş.tar.15.02.2019

https://www.cnnturk.com/ajanda/cernobilde-ne-oldu-iste-chernobyl-dizisinde-anlatilan facianin-detaylari" Erişim Tarihi: 08.10.2019.

IOM (2020). History International Organization for Migration. Erişim Tarihi: 04.03.2020 https://www.iom.int/iom-history 
IOM (2020). World Migration Report 2020: Chapter 2. Migration and Migrants: A Global Overview. International Organization for Migration. Erişim Tarihi: 21.10.2020. https://publications.iom.int/system/files/pdf/wmr_2020_en_ch_2.pdf.

IOM, (2009). International Organization for Migration. Uluslararası Göç Hukuku Göç Terimleri Sözlüğü. İsviçre. s.22.

İçduygu, A. (2004). Demographic Mobility and Turkey: Migration Experiences and Government Responses. Mediterranean Quarterly, Fall.

İçduygu, A. ve Sirkeci, İ. (1999). Cumhuriyet Dönemi Türkiye'sinde Göç Hareketleri, 75 Yılda Köylerden Şehirlere, İstanbul: Tarih Vakfi, 249-268.

İçduygu, A. ve Toktaş, S. (2005). Yurtdışından Gelenlerin Nicelik ve Niteliklerinin Tespitinde Sorunlar. Ankara: TUBA Raporları, Sayı 12.

İçduygu, A., fi. Toktafl and B. A. Soner, 2008, "The Politics of Population in a Nation Building Process: Emigration of Non-Muslims from Turkey", Ethnic and Racial Studies, 31(2): 358-389

İstanbul Sanayi Odası (iSO), 2001, Türkiye Ekonomisi, İstanbul: iso Yayını

İşçan ve Çakır , ( 2019), Türkiye 'Deki Sığınmacı ve Mültecilerin Türk İşgücü Piyasına Etkisi : Bir Saha Araşttrması Yıl: 19 Sayı: 43 Tarih: Nisan - Haziran 2019 ISSN: 21489424 s. 184.

https://www.iletisim.gov.tr/turkce/yerel_basin/detay/suriyeli-vatandaslara-turkce-dil-egitimleri-basliyor ,2020

Jean Baptise Meyer, Merey Brown, "Scientific Diasporas: A New Approach to the Brain Drain", Paper Prepared for the UNESCO-ICSU world Conference on Science, Budapest, June 1999, s. 2

Kahraman, S. (2016). Türkiye'de Göç Yönetişimi ve Suriyeli Sığınmacılar Yüksek Lisans Tezi. Selçuk Üniversitesi Sosyal Bilimler Enstitüsü Dergisi. Cilt: 2 Sayı: 11 ss. 299305

Kandemir Orhan, (2010), İktisadi Gelişme Sürecinde Göç Olgusu: Türkiye Örneği, Sakarya Üniversitesi, Sosyal Bilimler Enstitüsü, Sakarya, (Doktora Tezi) s.123

Kap, D. (2014). Suriyeli Mülteciler: Türkiye'nin Müstakbel Vatandaşları. Akademik Perspektif. ss 30-35.

Karabaş, B. (2018). Suriyeli Göçmen Çocukların Ev Bağlamında Mekânla Olan iliş̧kileri Ve Türkiye'ye Uyum Süreçlerinde Çocukluk Deneyimleri. Hacettepe Üniversitesi, Sosyal Bilimler Enstitüsü, Sosyal Hizmetler Anabilim Dalı, Yüksek Lisans tezi.

Karakayalı, T. (2010). Avrupa Birliği göç ve sığınma politikası ve Türkiye. Marmara Üniversitesi, Avrupa Birliği Enstitüsü, Avrupa Birliği Siyaseti ve Uluslararası Iliş̧kiler Anabilim Dalı, Yüksek Lisans tezi.

Karakuş, M. (2007). Türk göçmen gençlerin Almanya'ya uyumu. Sabancı Üniversitesi, Sosyal Bilimler Enstitüsü, Avrupa Çalışmaları Anabilim Dalı, Yüksek Lisans tezi.

Karaşahin, M. (2012). Avrupa birliği'nde ortak göç politikası oluşturma çabaları ve ulusal farklılıklar sorunu. Gazi Üniversitesi, Sosyal Bilimler Enstitüsü, Uluslararası İlişkiler Anabilim Dalı, Yüksek Lisans tezi

Kartal, H.(2008) Avrupa Birliğinin Yasadışı Göç Politikası ve Türkiye’ye Yansımaları, Yüksek Lisans Tezi. Gazi Üniversitesi Sosyal Bilimler Enstitüsü.

Kasdemir, B. (2010). Türkiye'de Sığınma Hareketi: Eskişehir Örneği, Yüksek Lisans Tezi, Anadolu Üniversitesi Sosyal Bilimler Enstitüsü, Eskişehir. 
Kaya, E.(2018). Avrupa Birliği'nde göçmen öğrencilerin eğitime entegrasyonu: Katalonya örneği. İstanbul Üniversitesi, Sosyal Bilimler Enstitüsü, Avrupa Birliği Anabilim Dalı. Yüksek Lisans tezi.

Kaya, S. (2015). İstanbul'a Göç Eden Ailelerde Gençlerin Adaptasyon Sorunları Ve İstihdam Etkileri. Beykent Üniversitesi, Sosyal Bilimler Enstitüsü, İşletme Yönetimi Anabilim Dalı, Yüksek Lisans tezi.

Kaya, Y. Ve Eren, Y. E. (2015). Türkiye'deki Suriyelilerin Hukuki Durumu Arada Kalanların Hakları ve Yükümlülükleri. İstanbul.

Kaygısız, İ. (2017). "Suriyeli Mültecilerin Türkiye İşgücü Piyasasına Etkileri", Friedrich Ebert Stiftung, http://www.fes-tuerkei.org/media/pdf/ (Erişim Tarihi: 12 Eylül 2019).

Kılıç, S. (2008).Çevre Etiği, Orion Kitabevi, Ankara

Kirişci, K. (2014), "Misafirliğin Ötesine Geçerken: Türkiye'nin "Suriyeli Mülteciler" SInavı" Brookings Enstitüsü \& Uluslararası Stratejik Araştırmalar Kurumu (Usak) Haziran 2014.

Kirişçi, K. (2000). Disaggregating Turkish Citizenship and Immigration Practices, Middle Eastern Studies, Volume 36-3, s. 1-22'den aktaran Aslı Didem Danış, Yeni Göç Hareketleri ve Türkiye, Birikim, No 184-185, s. 216-22,

Kiriş̧̧i, K. ve Karaca, S. (2015). Hoşgörü ve Çelişkiler: 1989, 1991 ve 2011'de Türkiye'ye Yönelen Kitlesel Mülteci Akınları, Ed. Erdoğan, M. M. ve Kaya, A., Türkiye'nin Göç Tarihi: 14. Yüzyıldan 21. Yüzyıla Türkiye'ye Göçler, 1. Baskı, İstanbul: İstanbul Bilgi Üniversitesi Yayınları, ss. 295-314.

Koser, K. and Pinkerton, C. (2002). The Social Networks of Alysum Seekers and the Dimmesnions of Information about Countries of Asylum. UK Home Office Research, Development and Statics Directorate, London. s.36

Köse, S. C. (2012). Çokkültürcülük politikalarından entegrasyon politikalarına geçiş: Hollanda'daki Türkiye kökenli göçmenler üzerine bir inceleme. Hacettepe Üniversitesi, Sosyal Bilimler Enstitüsü, Siyaset Bilimi ve Kamu Yönetimi Anabilim Dalı, Yüksek Lisans tezi.

Kramer, R. M., \& Brewer, M. B. (1984). Effects Of Group İdentity On Resource Use İn A Simulated Commons Dilemma. Journal of Personality and Social Psychology, 46(5), 1044-1057. https://doi.org/10.1037/0022-3514.46.5.1044

Kurt, H. (2006). Göç Eğilimleri ve Olası Etkileri. Yönetim Bilimleri Dergisi, Cilt: 4, Sayı: 1. ss.148-178.

Kuzucu, R. (2018). Türkiye'ye gelen Suriyelilerin ekonomiye etkisi: Gaziantep örneği.

Külek, C. (2018). Zorunlu Göçün Mekândaki Toplumsal Ve Ekonomik Etkileri: Bağcılar İlçesindeki Suriyeliler Örneği. Çanakkale Onsekiz Mart Üniversitesi, Sosyal Bilimler Enstitüsü, Coğrafya Anabilim Dalı, Yüksek Lisans tezi.

Kymlicka, W. (2015). Çok kültürlü yurttaşlık (Çev: A. Yılmaz). İstanbul: Ayrınt Yayınları

Lee, Everett S. (1969). "A Theory Of Migration”, Migration, ed. J.A. Jackson, Cambridge University Press, London, S. 282-297

Lordoğlu, K., \& Aslan, M. (2015). Beş Sınır Kenti ve İşgücü Piyasalarında Değişim: 20112014. Göç Dergisi, 2(2), 249-267.

Malkara, F. (2015). Arap Baharı sonrası Akdeniz'de yaşanan düzensiz göçün Avrupa Birliği kapsamında güvenlik boyutu ve uluslararası hukuk açısından incelenmesi. İzmir Katip Çelebi Üniversitesi, Sosyal Bilimler Enstitüsü, Uluslararası İlişkiler Anabilim Dalı, Yüksek Lisans tezi. 
Massey Douglas; Joaquin Arango, Graeme Hugo, Ali Kouaouci, Adela Pellegrino ,J. Edward Taylor (2014), Uluslararası Göç Kuramlarının Bir Değerlendirmesi, çev; S. Dedeoğlu, B. Oskay, Ç. Özbek, I. Sirkeci, M. M.Yüceşahin, Cilt: 1, Sayı: 1, sf. 11 - 46 ISSN: 2054-7110 | e-ISSN: 2

Massey, D.S. Arango , J. Hugo, G. Kouaouci, A. Pellegrino, A. Taylor, J.E. (1993). Population and Development Review. S.440054-7129.

Mcknown, A. (2004). “Global Migration 1846-1940". Journal of World History. Cilt: 15 (Adam Mckown2004.pdf, 19 Temmuz 2019 )

Mummendey, A., \& Schreiber, H.-J. (1983). Better or just different? Positive social identity by discrimination against, or by differentiation from outgroups. European Journal of Social Psychology, 13(4), 389-397.

Mutluer, K.(1990). Türk Vergi Sistemi-Yorum Çeşitli Açılardan Vergileme ve Sorunları. VI. Türkiye Maliye Eğitimi Sempozyumu, Ankara.

Mültecilerin Hukuki Statüsüne İlişkin 1951 Sözleşmesi ve 1967 Protokolü Çerçevesinde Mülteci Statüsünün Belirlenmesinde Uygulanacak Ölçütler ve Usuller Hakkında Elkitabı, BMMYK, Yeniden Gözden Geçirilmiş Baskı, Ağustos 1998.

https://multeciler.org.tr/,2020

Newman, E. , and J. Van Selm.( 2003). Refugees and forced displacement: International security, human vulnerability, and the state. New York: United Nations University Press.

Odman, T. (1995). Mülteci Hukuku. Ankara:Ankara Üniversitesi SBF İnsan Hakları Merkezi Yayınları.

Oğuzkan, T. (1971). Yurt Dışında Çalışan Doktoralı Türkler; Türkiye'den Başka Ülkelere Yüksek Seviyede Eleman Göçü Üzerinde Bir Araştırma. ODTÜ, Fen ve Edebiyat Fakültesi Yayını, No. 23, Ankara, Başnur Matbaası, 1971, s. 2

Oktik, N. (1997), "Köyün Çekiciliği Kentin İticiliği", Toplum ve Göç II. Ulusal Sosyoloji Kongresi, Sosyoloji Derneği, Ankara.

Öner, O. (2015). Bazı Türk Fabrikalarında Yaparak Öğrenme . Ankara Üniversitesi SBF Dergisi, 37 (1).

Özaydın, A. Ve İlgazi, A. (2019). Doğrudan Yabancı Sermaye Yatırımı Açısından Suriyeli Sığınmacılar. Gaziantep Üniversitesi İktisadi İdari Bilimler Fakültesi Dergisi. Cilt:1, sayı: 1 , ss.131-134.

Özcan, M. (2018). Göç eden kadınların aile geçim stratejilerindeki rol değişimleri: İstanbulıda yaşayan suriyeliler örneği. Üsküdar Üniversitesi, Sağlık Bilimleri Enstitüsü, Sosyal Hizmetler Anabilim Dalı, Yüksek Lisans tezi.

Özcan, O. (2013). Avrupa Birliği ve Yasadışı Göçmen/Mülteci Sorunu: Sınır Güvenliği ve Türkiyesye Etkileri. Yayınlanmamış Yüksek Lisans Tezi. Harp Akademileri Komutanlı̆̆ı. Stratejik Araştırmalar Enstitüsü.

Özdek, E. Yasemin (1993), "1990’larda İnsan Hakları: Sorunlar ve Yönelimler", İnsan Hakları Yıllığı, Cilt 15, s. 3-44.

Özdemir, I. (2003) "Toward an Understanding of Environmental Ethics from a Qur'anic Perspective" Foltz, R. C. Denny, F. M. Baharuddin A (Eds) Islam and Ecology Harvard University Press Cambridge, ss. 3-37

Özdemir, N, G. (2015). Suriyesden 2010 yılı sonrası süreçte Türkiyesye zorunlu göçün sosyolojik etkileri.

Özdemir, T. Van İlinde Birleşmiş Milletler Mülteciler Yüksek Komiserliği'ne İltica Talebinde Bulunan Mültecilerin Sorunları Üzerine Bir Çalışma, Yüzüncü Yıl Üniversitesi. 
Özensel, E. (2012). Çokkültürlülük Uygulaması Olarak Kanada'da Çokkültürlülük. Journal of Academic Inquiries. Cilt: 7, Sayı: 1.

Özer, Y. Y. (2007). Avrupa Birliğiınde göçmenler ve yabancı düşmanlığı. Marmara Üniversitesi, Avrupa Birliği Enstitüsü, Avrupa Birliği Siyaseti ve Uluslararası İlişkiler Anabilim Dalı, Doktora tezi.

Özgür, O. (2013). Avrupa Birliği ve yasadışı göçmen/mülteci sorunu: Sınır güvenliği ve Türkiyesye etkileri. Harp Akademileri Komutanlığı, Stratejik Araştırmalar Enstitüsü, Strateji ve Stratejik Araştırmalar Anabilim Dalı, Yüksek Lisans tezi.

Özgür-Baklavacıoğlu, N. (2010). Dış politika ve göç: Yugoslavya'dan Türkiye'ye göçlerde Arnavutlar (1920-1990). Derin Yayınları. İstanbul. S. 34

Özkarslı, F. (2014). Suriyesden Türkiyesye göç ve Suriyelilerin enformel istihdamı (Mardin örneği) . Mardin Artuklu Üniversitesi . Sosyal Bilimler Enstitüsü.

Öztekin, G. (2013). Aynı yönde, Çiçekli, Yabancılar, s. 41; Çelikel/ s. 59, s.84

Özyakışır, D. (2013). Göç: Kuram ve Bölgesel Bir Uygulama. Ankara: Nobel Akademi Yayıncılık.

Parla, A., Danış, D., (2007-2008), “Yeni Göçmenlerin Örgütlenme Biçimleri: Bulgaristan Türkleri, Irak Türkleri ve Moldovalılar Üzerine Karşılaştırmalı Analiz, TÜBITAK Projesi.GE

Pazarcı, H.(2011). Uluslararası Hukuk, Turhan Kitabevi, Ankara, 2011.

Petersen, W. (1958), "A General Typology of Migration", Amerikan Sociological Review, Vol: 23. s.256-266.

Petersen, W. (1958). A General Typology Of Migration. American Sociological Review,23, 259

Portes and Bach. (1985). Latin Journey: Cuban and Mexican Immigrants in the United States. University of California Press, California.

Ravenstein, E. G. (1885) "The Laws of Migration”, Journal of the Statistical Society of London, 48(2), 42 - 43.

Ray, Brian (2003), "The Role of Cities in Immigrant Integration" http://www.migrationpolicy.org/article/role-cities-immigrant-integration (24.11.2019)

Reicher, S. D., Spears, R., \& Haslam, S. A. (2010). The social identity approach in social psychology. In M. Wetherell, \& C. T. Mohanty (Eds.), The Sage Handbook of Identities Sage.

Resmi Gazetede (2013), "Yabancılar ve Uluslararası Koruma Kanunu" 28615 sayılı $11 / 04 / 2013$

Sarıdoğan, S. (2018). Türkiye Avrupa Birliği ilişkilerinde göçün güvenlikleştirilmesi: Suriye mülteci krizi örneği. Eskişehir Osmangazi Üniversitesi, Sosyal Bilimler Enstitüsü, Uluslararası Ilişskiler Anabilim Dalı, Yüksek Lisans tezi.

Sarığlu, G. (2018). Türkiye'nin Misafirleri Suriyeli Mültecilerin Öteki Bağlamında Göçmen Deneyimi: Esenyurt Örneği. İstanbul Yeni Yüzyıl Üniversitesi, Sosyal Bilimler Enstitüsü, İletişim Yönetimi Anabilim Dalı / İletişim Bilimleri Bilim Dalı, Yüksek Lisans tezi.

Saydam, A. (2010), Kırım ve Kafkasya Göçleri (1856-1876), Türk Tarih Kurumu Basımevi, Ankara.

Saygın, S, Hasta, D. (2018). Göç, Kültürleşme ve Uyum. Psikiyatride Güncel Yaklaşımla , 10 (3) , 312-333.

Sayın, Ö. (2001). Gezegenemizin Küreselleşmesi. Sosyoloji Dergisi, (8) , 0-0 . Retrieved from https://dergipark.org.tr/tr/pub/sosder/issue/40979/495040. 
Sengstock, C. M. (2009). Voices of diversity multi-culturalism in America, Springer Media.

Sert, D. (2012) "Integration and/or transnationalism? The case of Turkish-German transnational space", Perceptions, 17(2), 85-102.

Sert, D. (2016) "Uluslararası Göç Yazınında Bütünleyici Bir Kurama Doğru”, Gülfer Ihlamur-Öner ve Aslı Şirin öner (der.) Küreselleşme Çağında Göç-Kavramlar, Tartışma$\operatorname{lar}$ (3. Baskı) içinde İstanbul: İletişim Yayınları, 29-47.

Sığınmacı Krizi Dublin Sözleşmesi'ni Askıya aldırdı. (2019). Erişim Tarihi: 10.07.2019 http://aa.com.tr/tr/dunya/siginmaci-krizi-dublin-sozlesmesini-askiya-aldirdi/12842.

Sönmez, Z. (2014), "Komşuda Kriz: Suriyeli Mülteciler" İnsani ve Sosyal Araştırmalar Merkezi. Aralık 2014.

Stalker P., (1994), "The work of strangers: A survey of international labour migration", Geneva, ILO.

Statistisches Bundesamt 2011, Statistics. Wiesbaden

Stouffer, S.A. (1940) "Intervening Opportunities: A Theory Relating Mobility and Distance", American Sociological Review, 5(6), 847-848.

Sutcliffe, B. (1998). Nacido en otra parte. Un ensayo sobre la migración internacional, el desarrollo y la equidad. Bilbao: Hegoa

Sümer, R. M. (2021). Suriyeli göçmenlerin toplumsal algılanışı (Şanlıurfa ili merkez ilçeleri örneği). İnönü Üniversitesi, Sosyal Bilimler Üniversitesi, Felsefe ve Din Bilimleri Ana Bilim Dalı.

Şengül, E. (2015). 2005-2014 yıllarında Federal Almanya göç ve entegrasyon politikaları. Ufuk Üniversitesi, Sosyal Bilimler Enstitüsü, Uluslararası İlişkiler Anabilim Dalı, Yüksek Lisans tezi.

T.C. İçişleri Bakanlığı Göç İdaresi Genel Müdürlüğü (02 Ocak 2020). http://www.goc. gov.tr/icerik3/gecici-koruma_363_378_4713, (02.01.2020).

T.C. Resmi Gazete, 11 Nisan 2013, No: 28615.

T.C. Resmi Gazete, 15 Ocak 2016, No: 29594.

Tajfel, H. (1982). Social psychology of intergroup relations. Annual Review of Psychology, 33, 1-39.

Tartanoğlu, Ş.(2010). Sosyal Dışlanma: Küreselleşme Perspektifinden Bir Kavramlaştırma Çabası.

Taşkın, K. (2018). Türkiye'deki Suriyeli Sığınmacıların Göç Süreçleri, Mekansal Etkileri Ve Yerli Halkla Uyumları: Ayvacık örneği. Çanakkale Onsekiz Mart Üniversitesi, Sosyal Bilimler Enstitüsü, Coğrafya Anabilim Dalı, Yüksek Lisans tezi.

Tavas, O.E. (2015). Türkiye'nin Avrupa Birliği'ne Tam Üyelik Sürecinde Uluslararası Göç Yönetimi Stratejisi: Bir Model Önerisi, Doktora Tezi, Gazi Üniversitesi, Sosyal Bilimler Enstitüsü, Ankara.

Thomas, I. (1938). Coal In The Commons.

ThoughtCo.(2019).https://www.thoughtco.com/what-is-multiculturalism-4689285 (adresinden 20.10.2019 tarihinde indirilmiştir).

K.D.K, (2018), TÜRKIYE BÜYÜK MILLET MECLISI KAMU DENETÇiLiĞi KURUMU s.238

Toi, M., \& Batson, C. D. (1982). More evidence that empathy is a source of altruistic motivation. Journal of Personality and Social Psychology, 43(2), 281-292. https:// doi.org/10.1037/0022-3514.43.2.281 
Toksöz, G. (2006), Uluslar Arası Emek Göçü, İstanbul Bilgi Üniversitesi Yayınları, İstanbul.

Topal A.H. (2015). Geçici Koruma Yönetmeliği ve Türkiye'deki Suriyelilerin Hukuki Statüsü, İstanbul Medipol Üniversitesi Hukuk Fakültesi Dergisi, Sayı: 1, Cilt: 2: s.14.

Toprak, A. (2018). Türkiye'ye göç eden Suriyelilerin kültürel adaptasyonu Siirt örneği. Ankara Yıldırım Beyazıt Üniversitesi, Sosyal Bilimler Enstitüsü, Sosyoloji Anabilim Dalı, Yüksek Lisans Tezi.

Tunç, A. (2015). Mülteci Davranışı ve Toplumsal Etkileri: Türkiye'deki Suriyelilere İlişkin Bir Değerlendirme, Tesam Akademi Dergisi, Sayı 2,Cilt 2, 42-45.

Tunç, A. Ş. (2015), “Mülteci Davranışı ve Toplumsal Etkileri: Türkiye'deki Suriyelilere İlişkin Bir Değerlendirme", Tesam Akademi Dergisi, Cilt 2, Sayı 2, 29-63.

Turner, J. (1982). Toward a cognitive definition of the group. In H. Tajfel (Ed.), Social Identity and Intergroup Relations. Cambridge Cambridge University Press. s.33

Turner, J. (1987). Rediscovering the social group: A şelf categorization theory. Oxford: Basil Blakcwell.

Turner, J. (1991). Mapping social psychology series. Social influence. Thomson Brooks/ Cole Publishing Co. Califorina.

Turner, J. C. (1975). Social comparison and social identity: Some prospects for intergroup behaviour. European Journal of Social Psychology, 5(1), 5-34.

Turner, J. ve Brovvn, R. (1978). "Social status, cognitive alternatives and intergroup relations." Differentiation betiveen social groups: Studies in the social psychology of intergroup relations. (Der.) H. Tajfel. London: Academic Press. 201-300.

Türker, D. \& Yıldız, A. (2015). Göçmenlerde sosyo-psikolojik entegrasyon analizi, Betül Dilruba Şeker, İbrahim Sirkeci ve M. Murat Yüceşahin (Eds.), Göç ve Uyum, içinde (ss. 23-31). Transnational Press. Londra.

Türkiye Göç Raporu, 2016: 38-39

Ultan, M. Ö. (2015). Avrupa Birliği'nde yasadışı göçün önlenmesi ve ülke uygulamaları. İstanbul Üniversitesi, Sosyal Bilimler Enstitüsü, Avrupa Birliği Anabilim Dalı, Doktora tezi.

Unat, B. D. (2015). Türkiye'de yaşayan Suriyeli göçmenlerin gündelik yaşam pratikleri: Mardin örneği. Muğla Sıtkı Koçman Üniversitesi, Sosyal Bilimler Enstitüsü, SosyoIoji Anabilim Dalı. Yüksek Lisans Tezi.

UNHCR (2004) An Introduction to International Protection. (Metin içinde yok !!)

UNHCR (2017) metinde var kaynakçada yok !!!!

UNHCR (2019). Dünya Çapında Yerinden Edilmiş Kişi Sayısı 70 Milyonu Geçerken, Bm Mülteciler Yüksek Komiseri Duruma Müdahale İçin Daha Güçlü Bir Dayanışma Çağrısında Bulunuyor. https://www.unhcr.org/statistics/unhcrstats/5d08d7ee7/ unhcr-global-trends-2018.html

UNHCR (2020) Global Trends: Forced Displacement in 2018. Erişim Tarihi: 07.10.2019 https://www.unhcr.org/statistics/unhcrstats/5d08d7ee7/unhcr-global-trends-2018.html.

UNHCR. (1997-1998). Dünya Mültecilerinin Durumu: Bir İnsanlık Sorunu, s. 210-212.

Uzun, Elif, (2012), “Geri Göndermeme (Non-Refoulement) illkesinin Uluslararası Hukuktaki Konumu Üzerine Bir Değerlendirme", Uluslararası Hukuk ve Politika, Cilt: 8, Sayı:30, s. 25-58.

Üçgöz, P. (2003). Kültürlerarası İletişim, Üstün Eserler Neşriyatevi, İstanbul. 
Ünlü, H. G. (2009). Avrupa Birliği vatandaşlığı ve göçmenlik. Bahçeşehir Üniversitesi, Sosyal Bilimler Enstitüsü, Avrupa Birliği Siyaseti ve Uluslararası İlişkiler Anabilim Dalı, Yüksek Lisans Tezi.

GÜNAY, Ünver, (2003). "XV. Yüzyıl Osmanlı Toplumunda Sosyo-Kültürel Yapı, Din ve Değişme”, Erciyes Üniversitesi Sosyal Bilimler Enstitüsü Dergisi, Sayı: 14, Kayseri.

Vardar, E. (2018). Soğuk savaş sonrası dönemde Avrupa Birliği - Türkiye ilişkilerinde göç olgusunun analizi. Bursa Uludağ Üniversitesi, Sosyal Bilimler Enstitüsü, Uluslararası İlişkiler Anabilim Dalı, Yüksek Lisans tezi.

Vatandaş, S. (2016). Avrupa'ya Göçmen Akışı ve Türkiye'de Göç Politikaları. İlke İlim Kültür Eğitim Derneği(3), s.4.

Vertovec, S. (2002) "Transnational Networks and Skilled Labor Immigration", Working Paper for Ladenburger Diskurs "Migration" Gottlieb Daimler- und Karl BenzStiftung, Ladenburg, 14-15 February.

Wetherell, M. (1996). Group Conflict And The Social Psychology Of Racism. In M. Wetherell (Ed.), Identities, Groups And Social İssues (p. 175-238). Sage Publications, Inc; Open University Press.

White ve Woods. (2017). Zorunlu Göçler: Yerel Çatş̧malar ve Uluslararası İkilemler. (Çev: Özcan G). Annals of the Association of American Geographers, (Orijianal makalenin yayın tarihi: 1980).

www.tuik.gov.tr (son erişim tarihi:20.05.2019)

Yalçın C. (2010). Türkiye'de Kentlileşme Sorunları Üzerine Bir Tartışma, H.Ü. İktisadi ve İdari Bilimler Fakültesi Dergisi, Cilt 28, Sayı 1, 2010, s. 225-245.

Yalçın, C. (2004) Göç Sosyolojisi, Ankara: Anı Yayıncılık.

Yaman, F. (2018). Almanya'da çocukları koruma altına alınan göçmen ailelere yönelik koruma hizmetlerinin incelenmesi. Hacettepe Üniversitesi, Sosyal Bilimler Enstitüsü, Sosyal Hizmetler Anabilim Dalı, Doktora Tezi.

Yardımcı, Ş. (2018). Çalışma Hayat Uluslararası Düzensiz Göçle Karşılaşttğında: Şanlıurfa İlindeki Suriyeli Göçmenlerin Durumu. Anadolu Üniversitesi, Sosyal Bilimler Enstitüsü, İşletme Anabilim Dalı / Uluslararası İşletmecilik Bilim Dalı, Yüksek Lisans tezi.

Yavuz, D. G. (2007). Türkiyenin Avrupa Birliğine katllımı: Göçün olası rolü. Sabancı Üniversitesi, Sosyal Bilimler Enstitüsü, Avrupa Çalışmaları Anabilim Dalı, Yüksek Lisans tezi.

Yavuz, Ö. \& Yavaş, H. (2015). Türk Afet Yönetiminde Merkezileşme Sorunu ve Yerelleşme Çabası. Erişim Tarihi: 06.10.2020 https://www.researchgate.net/publication/282848904_Turk_Afet_Yonetiminde_Merkezilesme_Sorunu_ve_Yerellesme_ Cabalari

Yavuz, S. (2013),“Göç, Entegrasyon ve Din: Avrupa'da Yaşayan Türkler Bağlamında Bir Değerlendirme", Uluslararası Sosyal Araştırmalar Dergisi, Cilt 6, Sayı 26, 610-622.

Yayak, A. (2015). Göçmenlerin ayrımcılık ve kimlik algılarının nefret suçları kapsamında incelenmesi. İstanbul Üniversitesi, Adli Tıp Enstitüsü, Sosyal Bilimler Anabilim Dalı, Doktora tezi.

Yaylagül, C.. (2011). Göç Sorunu ve Yeni Göç Politikalarının Uygulamasında Kent Konseylerinin Birleşimi, www.academia.edu.tr

Yazan, Y. (2014). İnsan hakları bağlamında Avrupa Birliği'nin yasadışı göç politikası: Türkiye örneği. İstanbul Üniversitesi, Sosyal Bilimler Enstitüsü, Siyaset Bilimi ve Uluslararası İlişkiler Anabilim Dalı, Yüksek Lisans tezi. 
Yazıcı, A. (2010). Türk göçmenlerin Almanca öğretiminde yöntem ve öğretim boyutu. Hacettepe Üniversitesi, Sosyal Bilimler Enstitüsü, Alman Dili Eğitimi Anabilim Dalı, Yüksek Lisans tezi.

Yeğenağa, M. (2010). Avrupa Birliği ortak göç ve sığınma politikasına doğru. Bahçeşehir Üniversitesi, Sosyal Bilimler Enstitüsü, Avrupa Birliği İlişkileri Anabilim Dalı, Yüksek Lisans tezi

Yelutaş, N. (2001). Alman milli kimliğinin Almanya'daki Türk göçmenlerin kimlik oluşumundaki belirleyici rolü. Orta Doğu Teknik Üniversitesi, Sosyal Bilimler Enstitüsü, Sosyoloji, Yüksek Lisans tezi.

Yenigül, Sevinç Bahar (2005), Gazi Üniversitesi, Fen Bilimleri Enstitüsü, Çevre Bilimleri Anabilim Dalı ,06570, ISSN 1303-9709:273-288.

Yereli, A. N., \& Özdoğan, B. (2009). Genel kabul görmüş denetim standartlarının Türkiye açısından değerlendirilmesi. Celal Bayar’a Üniversitesi matbaası. s.13.

Yıldız T. ve Yıldız İ. (2017), "Suriyelilerin Türkiye Ekonomisinde Kayıt Dışı İstihdama Etkileri Ve Bunun Yansıması Olarak Türkiye'ye Maliyetleri Üzerine Bir İnceleme”, iktisadi İdari ve Siyasal Araşttrmalar Dergisi, Yıl:2017, Cilt: 2, Sayı: 3, ss.30-46.

Yıldız, A. (2017). Yıldız Ramazanoğlu'nun Hikâyelerinde Değişen Hikâye Boyutları. Sosyal Bilimler Araştırmaları Dergisi, 12 (1) , 207-216.

Yılmaz, A. (2014). Uluslararası göç: Çeşitleri, nedenleri ve etkileri. Electronic Turkish Studies, 9(2),1685-1704.

Yılmaz, E.A. ( 2019) , 2011 Sonrası Türkiye'ye Gelen Suriyelilerin Toplumsal Uyum Süreci Ve Sorunları: AYDIN ILINDE BIR ALAN ARAŞTIRMASI s.41. Doktora Tezi

Yılmaz, H. (2017). Nükleer Afetlerde Kriz Yönetimi. Yayımlanmamış Yülsek Lisans Tez: Gümüşhane Üniversitesi Sosyal Bilimler Enstitüsü, Gümüşhane.

Yiğit, R. (2017). Türkiye'nin Yeni Dönem Göç Politikaları Kapsamında Sivil Toplumun Yeri (Suriye Örneği), Kırıkkale Üniversitesi, Sosyal Bilimler Enstitüsü, Siyaset Bilimi ve Kamu Yönetimi Anabilim Dalı, Yüksek Lisans Tezi. 